\title{
Does ovarian sex cord tumour with annular tubules produce progesterone?
}

\author{
J DOLAN,* AH AL-TIMIMI, $\dagger$ SM RICHARDS,* JB JEFFS, $\ddagger$ GC MASON, \\ DB SMITH,§ PS HASLETON† \\ From the *Departments of Pathology and $\ddagger$ Gynaecology, Wythenshawe Hospital, Manchester, and the \\ Departments of Pathology, $\dagger$ St Mary's Hospital, Manchester, §the Christie Hospital, Manchester
}

SUMMARY Probable progesterone production was identified by an immunoperoxidase assay in a case of an ovarian sex cord tumour with annular tubules. The tumour was associated with a serous cystadenofibroma in the opposite ovary and with adenoma malignum (adenocarcinoma) of the cervix.

Sex cord tumour with annular tubules is a distinctive ovarian neoplasm, the prominent component of which shows morphological features intermediate between those of the granulosa cell tumour and those of the Sertoli cell tumour. Sex cord tumour with annular tubules is most commonly associated with hyperoestronism. ${ }^{1}$ This paper describes a case of sex cord tumour with annular tubules in which progesterone production was identified. The tumour was associated with a serous cystadenofibroma in the opposite ovary and adenocarcinoma of the cervix.

\section{Case history}

The patient, a 49 year old garage receptionist, presented in 1983 with a 12 month history of increasing - abdominal distension, anorexia, weight loss, and, more recently, episodes of diarrhoea. Menstruation had occurred regularly until December 1981, after which she had had continuous vaginal bleeding for about 12 months followed by eight months of amenorrhoea before admission. She had attended a homeopath for six months before consulting a general practitioner, who confirmed that she had received no hormone treatment. There were no family history of the Peutz-Jegher's syndrome.

She was thin and anxious. Foci of vitiligo were seen on the face and there were areas of brown colouration on the back of the hands (Fig. 1). The abdomen was grossly distended with severe ascites and a large irregular mass arising from the pelvis. Severe ankle oedema was also present. There were no stigmata of Peutz-

Accepted for publication 12 September 1985
Jegher's syndrome or virilism. Vaginal examination showed that she was virgo intacta. The perineal, anal and vaginal areas were extensively covered with velvety pigmented foci (Fig. 2). Table 1 shows the biochemical data preoperatively and postoperatively.

Ultrasonographic scanning confirmed the presence of a solid ovarian tumour with cystic foci. A smaller solid mass was seen deep in the pouch of Douglas. The uterus was enlarged and separate from the two other masses. Ascites was present, but there was no evidence of any metastases.

At laparotomy findings included 3 litres of ascites,

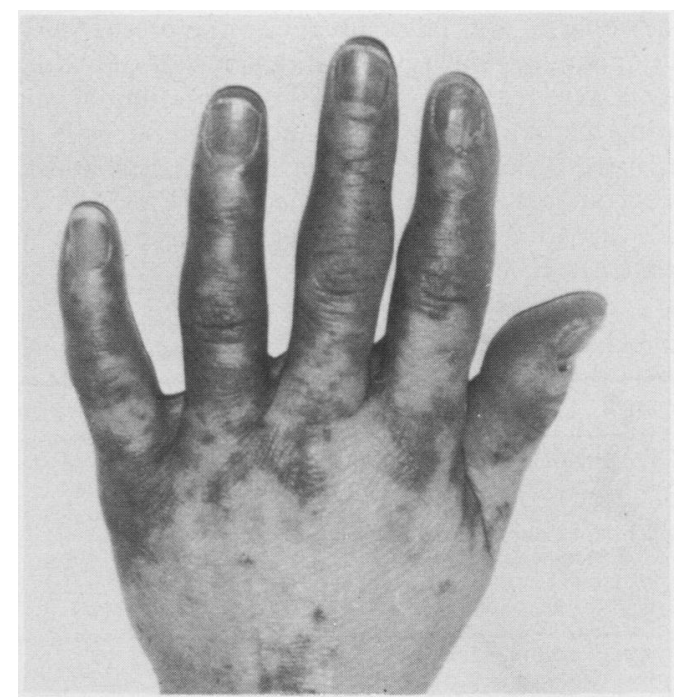

Fig. 1 Foci of brown colouration on back of hands. 


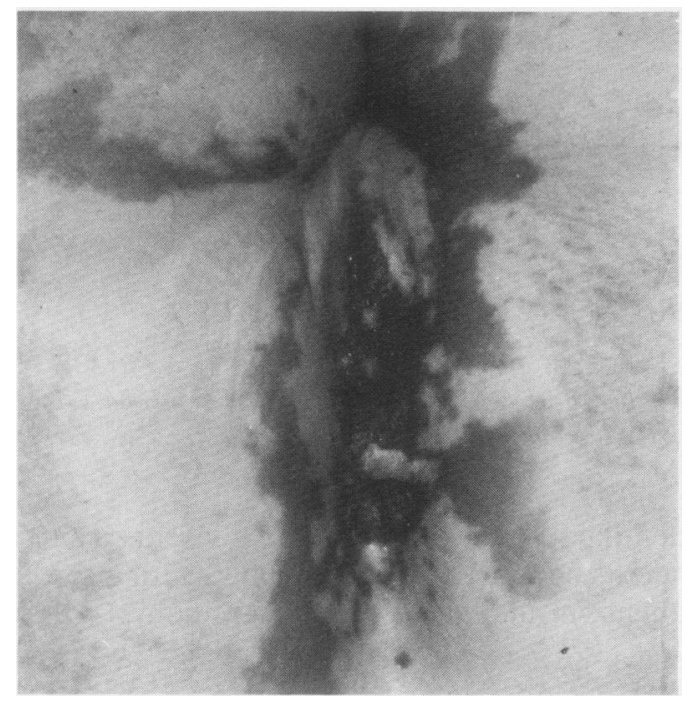

Fig. 2 Brown colouration of perianal region with pigmented naevi.

a 20 week uterus, a right ovary the size of a football and adherent to both the transverse colon and appendix. The left ovary was the size of a golf ball, which was also adherent to the left broad ligament and the posterior surface of the uterus. There was no evidence of metastatic disease.

A hysterectomy, bilateral salpingo-oophorectomy, and appendicectomy were performed.

\section{Material and methods}

\section{MACROSCOPIC FINDINGS}

Both ovaries and fallopian tubes, the uterus, cervix, the appendix, and several fragments of pelvic ligaments were received. The right ovarian tumour, measuring $23 \times 17 \times 11 \mathrm{~cm}$ and weighing $3005 \mathrm{gm}$, consisted of lobulated, firm yellowish tissue and had a central area of liquefactive necrosis (Fig. 3). A capsule (up to $0.7 \mathrm{~cm}$ in thickness) was present and seemed to be intact.
The left ovary $(6 \times 3 \times 2 \mathrm{~cm})$ contained many small cysts up to $1.5 \mathrm{~cm}$ in diameter separated by firm yellowish-white tissue. The myometrium contained multiple fibroids (the largest measuring $7 \mathrm{~cm}$ in diameter). The endometrium, up to $1.5 \mathrm{~cm}$ in thickness, showed an undulating surface and protruded through the cervix forming a polyp $(4 \times 4 \times 2 \mathrm{~cm})$. The cervix was irregular and distorted by the polyp. A rim of vagina (up to $5 \mathrm{~cm}$ in length) was attached. The fallopian tubes and appendix were grossly unremarkable.

The excised tissues were fixed in $10 \%$ formol saline. Blocks from the specimens were conventionally processed and embedded in paraffin wax. Sections were cut at $5 \mu \mathrm{m}$ and stained with haematoxylin and eosin. Further sections of the right ovarian tumour were stained with periodic acid Schiff, oil red O, elastic van Gieson, alcian blue, and Martius scarlet blue.

\section{IMMUNOPEROXIDASE METHODS}

Serial $5 \mu \mathrm{m}$ formalin fixed paraffin embedded sections of both tumours and endometrium were assayed for progesterone receptors. The immunoperoxidase staining was performed using the double peroxidaseantiperoxidase method, using rabbit antiprogesterone antiserum at concentrations of 0.02 and $0.01 \mathrm{mg} / \mathrm{ml}$. (Calbiochem Behring, West Germany), ${ }^{2}$ as well as swine antirabbit serum (Dako) and rabbit peroxidaseantiperoxidase (Dako).

Controls included substitution of normal rabbit serum for the antiprogesterone antiserum; substitution of absorbed antiserum (500 $\mu \mathrm{g}$ progesterone 1 $\mathrm{ml}$ of 1:100 antiprogesterone antiserum for 24 hours) for the primary antiserum; late secretory endometrium, which was consistently positive for progesterone receptors during initial experimentation, as a positive control; tissue sections from lung and muscle as negative controls; and omission of the initial hormone incubation as an endogenous hormone control designed to detect progesterone bound to the receptors in vivo and fixed in vitro at the time of biopsy.

The degree of receptor reactions was evaluated on

Table 1 Biochemical findings of peripheral blood (preoperatively and 10 days postoperatively)

\begin{tabular}{|c|c|c|c|}
\hline Hormone & Preoperative & Postoperative & Normal range \\
\hline $\begin{array}{l}17 \beta \text { Oestradiol (pmol/l) } \\
\text { Progesterone (nmol/l) } \\
\text { Luteinising hormone (U/l) } \\
\text { Follicle stimulating hormone (U/l) } \\
\text { Androstenedione (nmol/l) } \\
\text { Testosterone (nmol/l) } \\
\text { Cortisol (0900 hours) (nmol/l) }\end{array}$ & $\begin{array}{c}6746 \\
63 \\
1 \cdot 4 \\
1 \cdot 1 \\
5 \cdot 6 \\
\mathrm{ND}^{2 \cdot 2}\end{array}$ & $\begin{array}{c}45 \\
3 \cdot 2 \\
1 \cdot 3 \\
1 \cdot 0 \\
5 \cdot 0 \\
0 \cdot 9 \\
809\end{array}$ & $\begin{array}{c}230-650^{*} \\
6-60^{*} \\
1 \cdot 5-13 \\
2 \cdot 0-10 \\
2 \cdot 0-10 \\
0-2 \\
175-720\end{array}$ \\
\hline
\end{tabular}

*Normal luteal phase values.

Conversion: SI to traditional units

Oestradiol $1 \mu \mathrm{mol} / 1 \approx 27.24 \mathrm{pg} / 100 \mathrm{ml}$; progesterone $1 \mathrm{nmol} / 1 \approx 31.45 \mathrm{ng} / 100 \mathrm{ml}$; androstenedione $1 \mathrm{nmol} / 1 \approx 28.44 \mathrm{ng} / 100 \mathrm{ml} ;$ testos-

terone $1 \mathrm{nmol} / 1 \approx 28.84 \mathrm{ng} / 100 \mathrm{ml}$; cortisol $1 \mathrm{nmol} / \mathrm{l} \approx 36.25 \mathrm{ng} / 100 \mathrm{ml}$. 


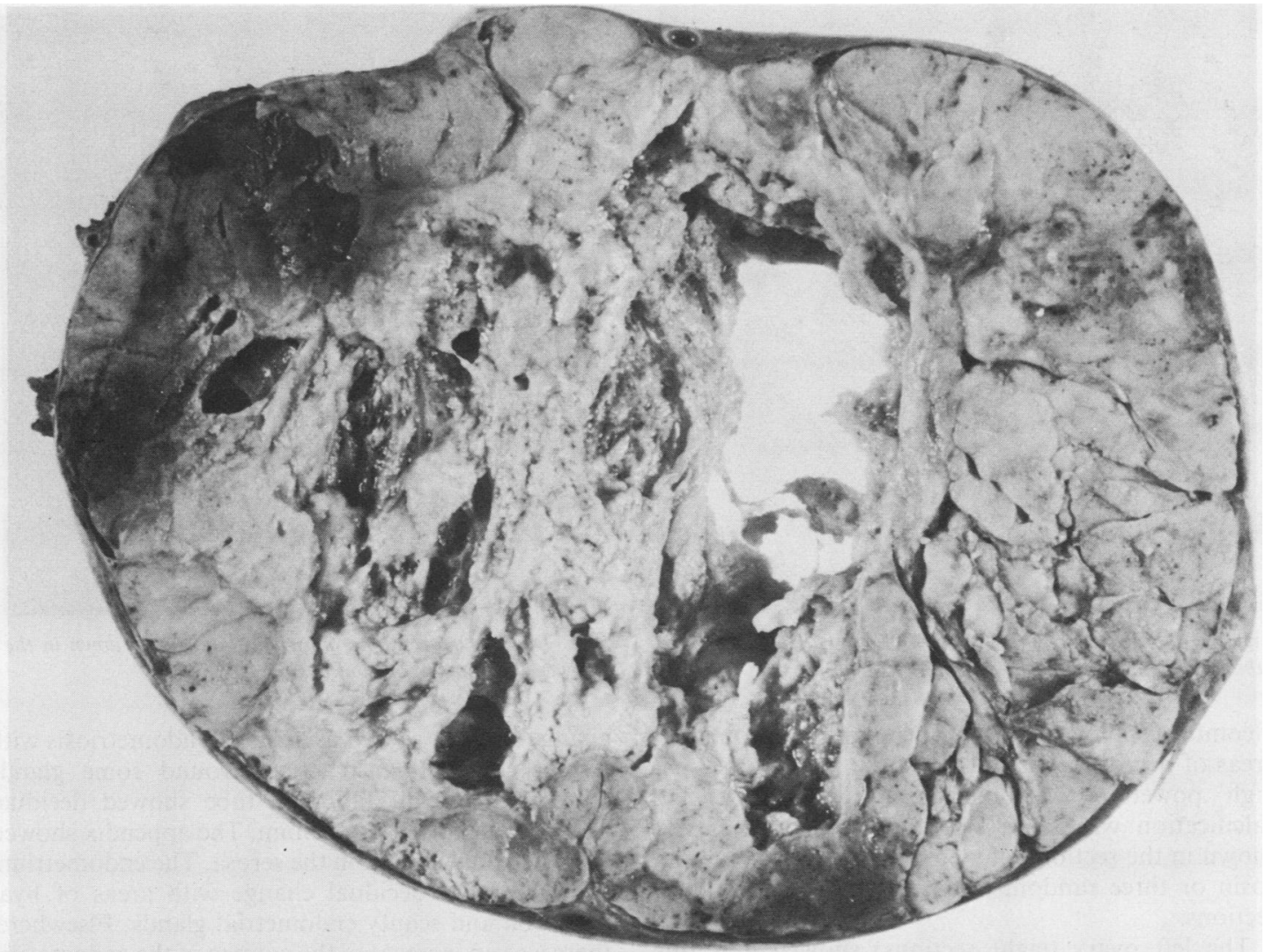

Fig. 3 Right ovarian tumour.

a semiquantitative basis from - to +++ , depending on the intensity of staining and the proportion of positive cells.

\section{HISTOPATHOLOGY}

The right ovarian tumour was a sex cord tumour with annular tubules (20 sections), comprising cellular islands with some trabeculae of cells set in a fibrous stroma (Fig. 4). Many of the cell groups showed peripheral pallisading. There was a predominantly granulosa pattern with some separate masses of pure granulosa cell tumour. Within some groups were simple and complex tubular lumina containing eosinophilic material (Fig. 4), while other groups contained ribbons of similar material. This material was positive for periodic acid Schiff and resistant for diastase, positive for alcian blue and negative for fibrin with the Martius scarlet blue stain. The nuclei were round and oval with a prominent nucleolus. The cytoplasm was faintly eosinophilic with varying degrees of vacuolation. An oil red $O$ stain showed deposits of intracytoplasmic lipids. Some nuclear

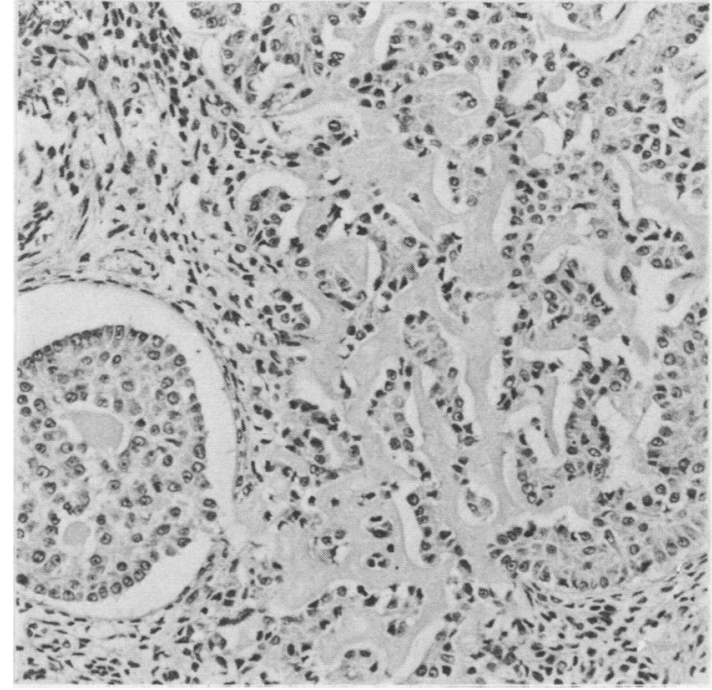

Fig. 4 Sex cord tumour with annular tubules showing tubules and fibrous stroma (haematoxylin and eosin) $\times 50$. 
Fig. 5 Mitotic figure in sex cord tumour with annular tubules (haematoxylin and eosin) $\times 200$.

pleomorphism was present around the prominent areas of necrosis. The mitotic count was up to 7 per high power ( $\times 40$ objective) field (Fig. 5). No calcification was seen. Vascular invasion was not shown in the sections stained with haematoxylin and eosin or three randomly stained elastic van Gieson sections.

The left ovary (eight sections) showed a serous cystadenofibroma with foci of borderline malignant

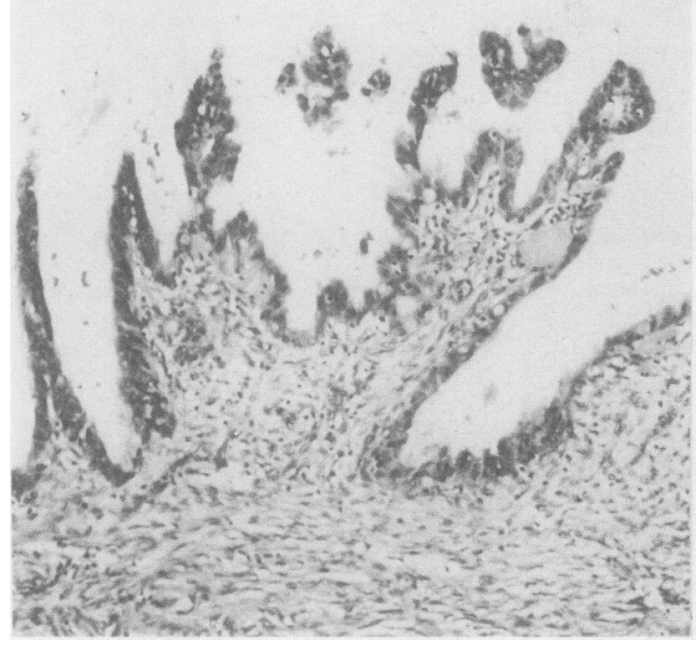

Fig. 6 Borderline change in left ovarian tumour (haematoxylin and eosin) $\times 50$.

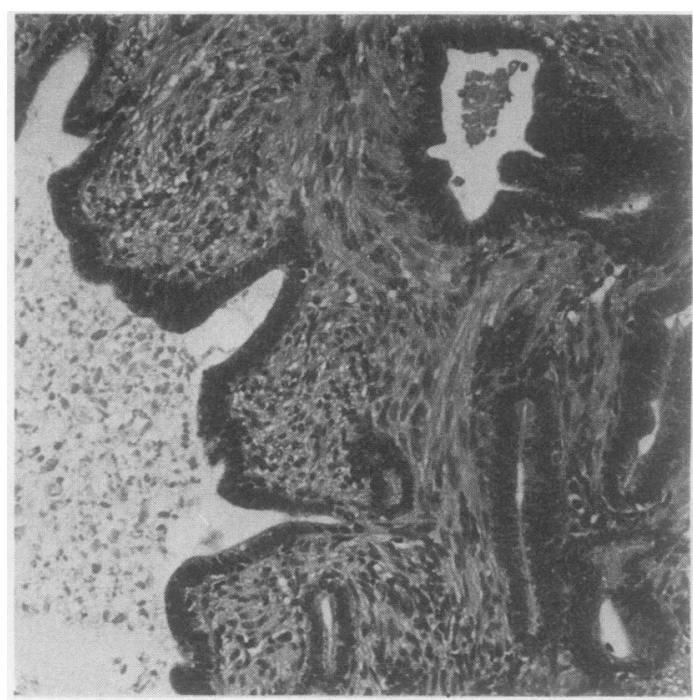

Fig. 7 Adenocarcinoma showing glands deep down in the cervix (haematoxylin and eosin) $\times 120$.

change (Fig. 6), as well as areas of endometriosis with a marked decidual reaction around some glands (Fig. 7). The right fallopian tube showed decidual change beneath the epithelium. The appendix showed focal decidual change in the serosa. The endometrium showed severe decidual change with areas of hyalinisation and scanty endometrial glands. Elsewhere, there was an increase in the volume of the endometrial

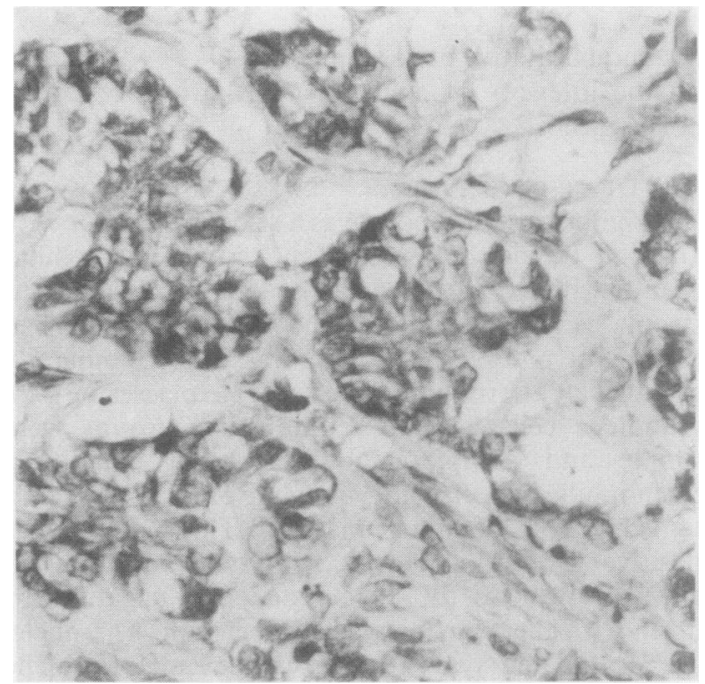

Fig. 8 Sex cord tumour with annular tubules showing positive staining for progesterone receptors in epithelial cells as well as some stromal cells (immunoperoxidase) $\times 200$. 
Table 2 Immunoperoxidase assay of sex cord tumour with annular tubules for progesterone receptors

\begin{tabular}{|c|c|c|c|c|c|}
\hline \multirow[t]{2}{*}{ Hormone pretreatment } & \multirow[t]{2}{*}{ Antibody } & \multicolumn{3}{|l|}{ Results } & \multirow[t]{2}{*}{ Interpretation } \\
\hline & & $\begin{array}{l}\text { Left ovary } \\
\text { (serous } \\
\text { cystadenofibroma) }\end{array}$ & $\begin{array}{l}\text { Right ovary } \\
\text { (sex cord tumour } \\
\text { with annular tubules }\end{array}$ & Endometrium & \\
\hline Progesterone & Antiprogesterone & + & $t+t$ & ++ & $\begin{array}{l}\text { Bound hormone plus } \\
\text { free receptor sites }\end{array}$ \\
\hline $\begin{array}{l}\text { None } \\
\text { Progesterone }\end{array}$ & $\begin{array}{l}\text { Antiprogesterone } \\
\text { Absorbed }\end{array}$ & - & + & + & Bound hormone \\
\hline Progesterone & $\begin{array}{l}\text { antisera } \\
\text { Normal rabbit } \\
\text { serum }\end{array}$ & - & - & - & $\begin{array}{l}\text { Control } \\
\text { Control }\end{array}$ \\
\hline
\end{tabular}

The positive control (human late secretory endometrium) gave a positive result.

Lung and muscle gave a negative result.

glands, which were dilated and in places showed a back to back arrangement. No nuclear pleomorphism was seen in the glands and there was no evidence of invasive carcinoma. The vagina and cervix showed adenomatosis. In some areas of the cervix the changes were those typical of adenoma malignum (adenocarcinoma) of the cervix (Fig. 8).

The stain using progesterone antiserum at a concentration of $1 / 50$ (Table 2 ) showed positive staining in the cytoplasm of the tumour cells of the sex cord tumour with annular tubules, including the tumour cells within the fibrous stroma. This reaction was as strong as that of in vitro receptor sites-that is, hormone preincubation and progesterone antiserum at $1 / 100$ dilution. This accentuation of reaction was not seen, however, in the serous cystadenofibroma or endometrium when treated in a similar way (Table 2).

\section{Discussion}

Sex cord tumour with annular tubules was first described in $1970 .^{3}$ It is a distinctive ovarian neoplasm, the prominent component of which shows morphological features intermediate between the granulosa cell tumour and the Sertoli cell tumour. Sex cord tumour with annular tubules is usually associated with hyperoestronism. ${ }^{1}$ One of the striking features of the present case, however, was the severe degree of decidual change both in the endometrium as well as in the extrauterine sites. This raised the possibility of a progesterone effect, but the patient denied taking any hormonal treatment before the operation. The general practitioner was contacted, and he confirmed that no drugs containing progesterone had been prescribed. The origin of the progesterone remained in doubt.

When detailed biochemical analysis of the peripheral blood from the patient preoperatively and 10 days postoperatively was undertaken. The preoperative progesterone concentration was $63 \mathrm{nmol} / 1$ (198.35 $\mathrm{ng} / 100 \mathrm{ml}$ ), which is just above the upper limit of normal for the luteal phase of the ovulatory cycle (60 $\mathrm{nmol} / 1,189 \mathrm{ng} / 100 \mathrm{ml})$. The serum values of both follicle stimulating hormone and luteinising hormone were both very low, however, possibly due to a negative feedback effect of the high oestradiol concentration, and this would be incompatible with a luteal phase effect. A postoperative blood sample showed that the progesterone concentration had dropped appreciably.

Therefore, suspecting that the sex cord tumour with annular tubules was producing progesterone and had stimulated tissue already primed by the high concentration of oestrogen, an immunoperoxidase stain was done on both ovarian tumours. This confirmed that the sex cord tumour with annular tubules had progesterone receptors. The method used first showed the progesterone that was already bound and after flooding with progesterone identified previously unoccupied receptor sites. Although the presence of progesterone receptors does not necessarily indicate that progesterone is being produced, it was the likely site of production of the hormone in this patient. The serous cystadenofibroma had a small amount of progesterone activity due to receptor site binding, but an increase in concentration of progesterone antiserum from $1 / 100$ to $1 / 50$ did not increase the intensity of staining of the serous cystadenofibroma or endometrium.

The immunoperoxidase technique cannot distinguish biosynthesis from intracellular storage or binding of steroids to specific hormone receptors in the cells. ${ }^{4}$ Thus the progesterone reactions were either receptor sites (free and occupied), synthesis sites, or storage sites. We thought that the reaction in sex cord tumour with annular tubules represented synthesis and storage.

The hormonal activity of sex cord tumour with annular tubules has not been studied directly, but indirect evidence seems to indicate that a hyperoestrogenic effect with endometrial hyperplasia is a 
Table 3 Comparison of cases of sex cord tumour with annular tubules with and without Peutz-Jegher's syndrome

\begin{tabular}{llcl}
\hline Sex cord tumour with annular tubules & $\begin{array}{l}\text { With Peutz-Jegher's } \\
\text { syndrome }\end{array}$ & $\begin{array}{l}\text { Without Peutz-Jegher's } \\
\text { syndrome }\end{array}$ & Present case \\
\hline Bilateral & $13 / 21$ & $0 / 17$ & Negative \\
Macroscopic & $11 / 40$ & $37 / 47$ & Positive \\
Multifocal & $23 / 40$ & $2 / 47$ & Negative \\
Calcification & $25 / 40$ & $3 / 47$ & Negative \\
Metastases & $0 / 27$ & $7 / 47$ & Negative \\
Adenoma malignum of cervix & $4 / 27$ & $0 / 47$ & Positive \\
\hline
\end{tabular}

Adapted from Young et al. ${ }^{1}$

common finding. Steenstrup, however, found normal urinary oestrogen concentration ${ }^{5}$ and Netter et al mentioned an oestrogen concentration at the upper limit of normal in one of their patients. ${ }^{6}$ Sex cord tumour with annular tubules is not known to produce progesterone, the rise of which may have accounted for the onset of amenorrhoea experienced by our patient for eight months before admission and may explain previous cases of sex cord tumour with annular tubules in which menstrual irregularities were followed by prolonged periods of amenorrhoea. ${ }^{17} \mathrm{~A}$ recent case report showed decidualisation of the endometrium in a sex cord tumour with annular tubules with endometrioid differentiation. ${ }^{8}$

Malignancy is a rare feature of sex cord tumour with annular tubules. In the study by Young et al mitotic figures were absent or very rare in most cases, and only seven of the 74 cases reviewed had clinical evidence of malignancy. ${ }^{1}$ When these malignant examples were studied in more detail the mitotic count varied from one to two per 10 high power fields. From seven to 10 mitotic figures per 10 high power fields have been reported in a malignant case. ${ }^{9}$ Hart et al observed mitotic figures in two malignant cases but did not state the incidence. ${ }^{7}$ The case of sex cord tumour with annular tubules reported here showed in places a mitotic count of seven per high power field, and, therefore, we predicted that the tumour would behave malignantly, although no metastases were noted at operation. Follow up of the patient at two months showed hepatomegaly, but liver function tests, oestradiol, and progesterone concentrations were normal. In the serial investigation conducted by Young et al of the seven cases in which the sex cord tumour with annular tubules was malignant, four of the patients died of their tumour between three and five years after the diagnosis was made. Hart et al took the view that it was no longer appropriate to regard sex cord tumour with annular tubules as a benign tumour when they reached a large size. ${ }^{7}$ The authors were of the opinion that a sex cord tumour with annular tubules behaves like granulosa cell tumours, which are of low grade malignancy and may produce metastases after latent intervals of many years.

Adenocarcinoma of the cervix is a rare cervical neoplasm, there being only about 20 cases previously described. The tumour is characterised by glands lined by well differentiated epithelium and which invade deeply into the cervical wall. ${ }^{10}$ Histologically benign glands can invade blood vessels, lymph nodes, and perineural spaces. In the series of Young et al only four of the 74 cases of sex cord tumour with annular tubules had adenocarcinoma. All these four patients had Peutz-Jegher's syndrome (PJS), and the sex cord tumour with annular tubules affected both ovaries and was microscopic in size. In our case the sex cord tumour with annular tubules was large, unilateral, and associated with adenocarcinoma. As mentioned above the patient had no family history or stigmata of Peutz-Jegher's syndrome, but no endoscopy, barium meal, or enema were done. Follow up of the patients with adenocarcinoma in association with sex cord tumour with annular tubules ${ }^{1}$ showed that the sex cord tumour with annular tubules did not metastasise in any case, but two women died as a result of spread of the adenocarcinoma.

Sex cord tumour with annular tubules has been associated with several findings in the opposite ovary. These have included a dysgerminoma ${ }^{11}$ and a mucinous cystadenofibroma. ${ }^{5}$ In our patient the sex cord tumour with annular tubules was associated with a serous cystadenofibroma showing borderline malignant change in the opposite ovary. There was no evidence of prominent progesterone receptors by this tumour. Another interesting feature of sex cord tumour with annular tubules is their prevalence among patients with Peutz-Jegher's syndrome, a familial disorder characterised by gastrointestinal polyps and melanin pigmentation of the oral mucosa, lips, and skin. Table 3 compares the incidence of sex cord tumour with annular tubules with and without Peutz-Jegher's syndrome. Comparison of our case of sex cord tumour with annular tubules with previous reports of the tumour in the absence of Peutz-Jegher's syndrome shows certain similarities; at operation the tumour was unilateral, macroscopic, and lacked calcification. Adenocarcinoma in the presence of sex cord tumour with annular tubules, however, has only been previously described in association with PeutzJegher's syndrome. 
We thank Dr WA Ratcliffe of the department of biochemistry, Hope Hospital, Salford, for her help with the biochemical analysis. We also thank Professor $\mathrm{H}$ Fox and Dr H Buckley of St Mary's Hospital, Manchester, for their most helpful advice, and to Mr RH Martin, consultant gynaecologist, Wythenshawe Hospital, Manchester, for permission to study this case. Mrs C Harris kindly typed the manuscript.

\section{References}

${ }^{1}$ Young RH, Welch WR, Dickersin GR, Scully RE. Ovarian sex cord tumour with annular tubules. Review of 74 cases including 27 with Peutz-Jegher's syndrome and four with adenoma malignum of the cervix. Cancer 1982:50:1384-402.

${ }^{2}$ Al-Timimi A, Buckley CH, Fox $\mathrm{H}$. An immunohistochemical study of the incidence and significance of sex steroid hormone binding sites in normal and neoplastic human ovarian tissue. International Journal of Gynaecological Pathology 1985:4:24-41.

${ }^{3}$ Scully RE. Sex cord tumour with annular tubules: a distinctive ovarian tumour of the Peutz-Jegher's syndrome. Cancer 1970:25: 1 107-21.

${ }^{4}$ Kurman RJ, Goebelsmann U, Taylor CR. Steroid localization in granulosa-theca tumours of the ovary. Cancer 1979:43:2377-84.

${ }^{5}$ Steenstrup EK. Ovarian tumours and Peutz-Jegher's syndrome. A case of sex cord tumour with annular tubules. Acta Obstet Gynecol Scand 1972:51:237-40.

${ }^{6}$ Netter AL, Netter A, Berger CH, Lansac J, Lecomta P. Ovarian tumour in Peutz-Jegher's syndrome. Nouv Presse Med 1975: 45:3181-2.

${ }^{7}$ Hart WR, Kumar N, Crissman JD. Ovarian neoplasms resembling sex cord tumours with annular tubules. Cancer 1980:45:2352-63.

${ }^{8}$ Czernobilsky B, Gaedcke G, Dallenback-Hellweg G. Endometrioid differentiation in ovarian sex cord tumour with annular tubules accompanied by gestagenic effect. Cancer 1985:55:738-44.

${ }^{9}$ Gloor E. Ovarian sex cord tumour with annular tubules. Virchows Arch (Pathol Anat) 1979:384:185-93.

${ }^{10}$ Silverberg SG, Hurt WG. Minimal deviation adenocarcinoma ("adenoma malignum") of the cervix. Am J Obstet Gynecol 1975:123:971-5.

${ }^{11}$ Tseng HL, Braunstein L. Polyposis of the small intestine. Gastroenterology 1954:27:426-30.

Requests for reprints to: Dr PS Hasleton, Department of Pathology, Regional Cardiothoracic Centre, Wythenshawe Hospital, Southmoor Road, Wythenshawe, Manchester, M23 9LT England. 